\title{
Foreign Direct Investment in Insurance Sector: A Key for Better Insurance Penetration
}

\author{
L. Terina Grazy, G.Parimalarani, M. Rathi Meena
}

\begin{abstract}
One of the most attractive developments during the last two decades is the brilliant growth of Foreign Direct Investment (FDI) in the global economy. Foreign direct investment is major source of non-debt financial resource for the economic development of India. Foreign companies invest in India to take advantage of lower wages, special investment such as tax exemptions, etc. The insurance sector has been fast developing with substantial revenue growth in insurance market. FDI in insurance would increase the penetration of insurance in India, FDI helps India in long term capital requirement to develop the infrastructures. Insurance sector is a booming industry in India with both National and International players competing and growing at rapid rate. Insurance Regulatory and Development Authority (IRDA) is in favour of an increase in foreign equity capital in the insurance joint venture. The public sector Insurance companies have continued to dominate the insurance market. India is among the most promising emerging insurance markets in the world. However the penetration of insurance coverage for both life and nonlife insurance is still very less and registered at $3.69 \%$ in 2019 . The main objective of this paper is to know the benefits of foreign direct investment in insurance sector, and to know the government initiatives regarding insurance sector.
\end{abstract}

Keywords : Insurance, Foreign direct investment, Penetration.

\section{INTRODUCTION}

The year 2001 witnessed a remarkable change in the Indian Insurance sector. The country experienced a notable history by liberalizing the insurance services by allowing private players to this enter field. Till that period the insurance sector was dominated by the public sector gains namely Life Insurance Corporation (LIC) and General Insurance Corporation (GIC). The liberalization has facilitated the private players which there by increased the number of insurance players to $52 \quad 924$ in Life insurance business and 28 non-life insurance). In India insurance plays a major role to mobilizing savings and channelize them into investment in different stores of the economy. Foreign Direct

Revised Manuscript Received on October 15, 2019.

* Correspondence Author

L.Terina Grazy, Ph.D Full Time Scholar, RUSA Fellow Alagappa Institute of Management, Alagappa University, Karikudi-630004, Tamil Nadu, India

Dr.G.Parimalarani, Associate Professor, Department of Banking Management, Alagappa University, Karikudi-630004, Tamil Nadu, India

M. Rathi Meena, Ph.D Full Time Scholar, ICSSR Fellow Alagappa Institute of Management, Alagappa University, Karikudi-630004, Tamil Nadu, India
Investment (FDI) in insurance increases the level of penetration insurance in India. FDI meet India's long- term capital requirements to build the required infrastructure. Insurance sector has the capability of raising long-term capital from the mass. Insurance is the only avenue where people put money for a long as 30 years even more. An increase in FDI in insurance would indirectly be a gain for the Indian economy. The insurance sector has also been fast developing with substantial revenue growth in the insurance market. At present there are 52 insurance companies operating in India. India's insurance sector is one of the largest in the world in terms of volumes of money involved. In 2015, Insurance Regulatory and Development Authority (IRDAI) raced the center on foreign ownership of India Insurers 49\% from 29\% encouraging global players to buy holding in local entitles. In recent budget the Finance Ministry has announced to hike the FDI in Insurance to $79 \%$. By taking this as a background the present study is undertaken.

\section{Objectives of the study}

The major objectives of the study are :

1. To give an overview of Indian Insurance sector.

2. To outline the importance of FDI in insurance sector.

3. To highlight the policies enforced by the government with respect to FDI in insurance sector

\section{REVIEWT OFT LITERATURE}

Vijay M. Kumbhar (2013), in his work analyzed the history of insurance sector of the private insurance companies and discussed about the growth trend in FDI in life insurance sector. Chandra Kantha. $\mathrm{K}$ and Ramachandra Gowda (2016) In their paper they examined the liberalization in insurance sector has brought positive changes in the industry and the strength of CSR for the growth of insurance industry. Rajesh K. Yadav, Sarvesh Mohania (2016) has opined that Indian insurance industry is less penetration and it has huge growth. Foreign direct investment (FDI) plays significant role in 
the developed country. M. Rajeev (2016) he discussed about the trend of general insurance sector in India, and the effect of FDI in the general insurance sector and also analyzed the significance of FDI for Indian general sector. Krunal Soni (2017) in his study has discussed about the foreign direct investment which can be done effectively only through increase in FDI and it enhances the overall performance of insurance sector. L.Terina Grazy and G. Parimalaran (2019) we discussed about whether social media marketing helps the customer to purchase policy in insurance sector. L. Terina Grazy and G. Parimalarani (2018) we study the growth trends of policy holders in micro insurance channels and to analysis the claim settlement made for the policyholders, L.Terina Grazy and G. Parimalarani (2018) we discussed about the corporate social responsibility initiatives taken by life insurance companies operating in India and descriptive the nature of CSR.

\section{INDIAN INSURANCE SECTOR}

The insurance Regulatory and Development Authority (IRDA) was constituted as an insurance industry. The IRDA was incorporated as a statutory body in April 2000. The key objectives of the IRDA include promotion of competition so as to enhance customer satisfaction through increased consumer choice and lower premiums. The IRDA opened up the market in August 2000 with the invitation for application for registrations. Foreign companies were allowed ownership of up to $26 \%$. The authority has the power to frame regulations under Section 114 (A) of the insurance Act, 1938 and has from 2000 onwards framed various regulations ranging from registration of companies for carrying insurance business to protection of policyholders interest. The LIC has monopoly till the 90s when the Insurance Sector was reopened to the private sector. Before that, the industry consisted of only two state insurers, namely Life Insurance Corporation of India and General Insurance Corporation of India. Registered insurers in India:

At the end of March 2018, there are 53 insurance companies operating in India, out of which 24 are in the life insurance business and 28 are in the non- life insurance business.

Table 1: Registered Insurers in India

\begin{tabular}{|c|c|c|c|}
\hline $\begin{array}{c}\text { Type of } \\
\text { business }\end{array}$ & $\begin{array}{c}\text { Public } \\
\text { sector }\end{array}$ & $\begin{array}{c}\text { Private } \\
\text { Sector }\end{array}$ & Total \\
\hline Life insurance & 1 & 23 & 24 \\
\hline General & 6 & 17 & 23 \\
\hline Health & 0 & 6 & 6 \\
\hline
\end{tabular}
autonomous body to regulate and develop the

\begin{tabular}{|c|c|c|c|}
\hline Reinsurance & 1 & 8 & 9 \\
\hline Total & 8 & 54 & 63 \\
\hline
\end{tabular}

Source: IRDA annual report 2018

\section{INSURANCE PENETRATION}

Table 2: Insurance Penetration and Density in India

\begin{tabular}{|l|c|c|c|c|}
\hline \multirow{2}{*}{\begin{tabular}{r} 
Yea \\
\cline { 2 - 5 }
\end{tabular}} & $\begin{array}{c}\text { Densit } \\
\mathbf{y} \\
\text { USD }\end{array}$ & $\begin{array}{c}\text { Penetratio } \\
\mathbf{n} \\
\text { \% }\end{array}$ & $\begin{array}{c}\text { Densit } \\
\mathbf{y} \\
\text { USD }\end{array}$ & $\begin{array}{c}\text { Penetratio } \\
\mathbf{n} \\
\mathbf{\%}\end{array}$ \\
\hline 2001 & 9.10 & 2.15 & 2.4 & 0.56 \\
\hline 2002 & 11.70 & 2.59 & 3.0 & 0.67 \\
\hline 2003 & 12.90 & 2.26 & 3.5 & 0.62 \\
\hline 2004 & 15.70 & 2.53 & 4.0 & 0.64 \\
\hline 2005 & 18.30 & 2.53 & 4.4 & 0.61 \\
\hline 2006 & 33.20 & 4.10 & 5.2 & 0.60 \\
\hline 2007 & 40.40 & 4.00 & 6.2 & 0.60 \\
\hline 2008 & 41.20 & 4.00 & 6.2 & 0.60 \\
\hline 2009 & 47.70 & 4.60 & 6.7 & 0.60 \\
\hline 2010 & 55.70 & 4.40 & 8.7 & 0.71 \\
\hline 2011 & 49.00 & 3.40 & 10.0 & 0.70 \\
\hline 2012 & 42.70 & 3.17 & 10.5 & 0.78 \\
\hline 2013 & 41.00 & 3.10 & 11.0 & 0.80 \\
\hline 2014 & 44.00 & 2.60 & 11.0 & 0.70 \\
\hline 2015 & 43.20 & 2.72 & 11.5 & 0.72 \\
\hline 2016 & 46.50 & 2.72 & 13.2 & 0.77 \\
\hline 2017 & 55.0 & 2.76 & 18.0 & 0.93 \\
\hline$S 09$ & & & & \\
\hline
\end{tabular}

Source: Compiled from IRDA Annual report 2011-2016

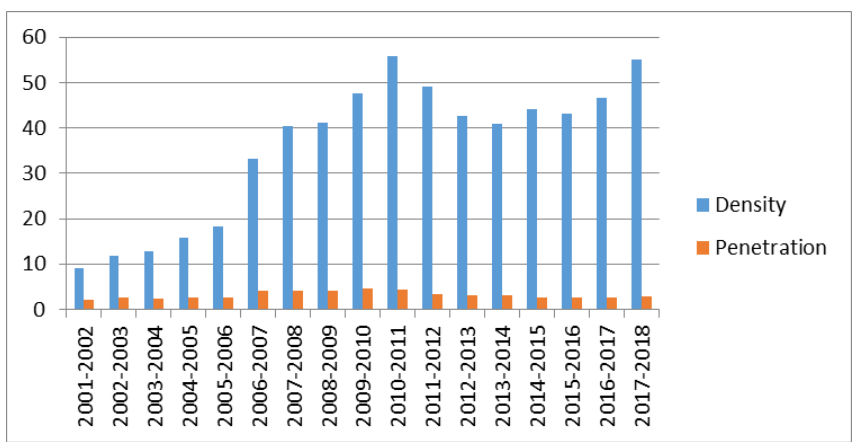

Figure 1: Insurance Penetration and Density in India

\subsection{Insurance Penetration and Density in India}

The performance and the development of the insurance sector in an economy are assessed through insurance penetration and insurance density. 
According to the IRDA Annual Report 2017-18 insurance penetration has steady increased from 2001 (2.15\%) to 2009 (4.60\%) after 2010 the percentage of penetration shows a declining trend. The year 2010 noticed the highest penetration of $4.60 \%$. After 2010 the percentage of penetration shows a declining trend. The year 2010 noticed the highest penetration of $4.60 \%$.
The insurance density of life insurance sector had insured from 9.10 (2001) to 55.70 (2010). Throughout the period fluctuating trend is noticed for the Life insurance density. From 2011 to 2017 the density increase it reached to 55.0 in 2017-2018.

\subsection{Global penetration}

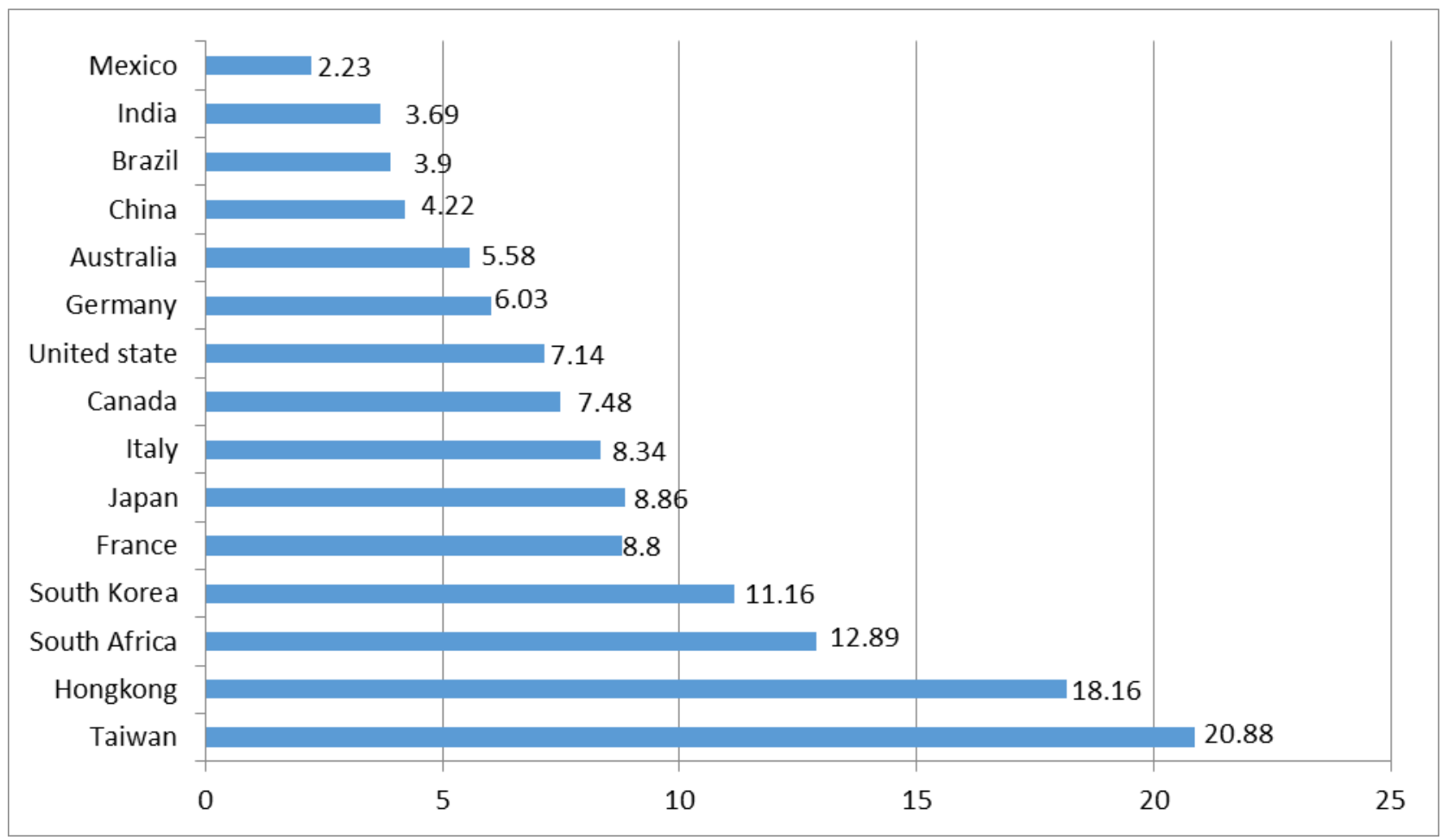

Figure 2: Global Insurance penetration 2018

\section{FOREIGN DIRECT INVESTMENT IN INDIA}

A foreign direct investment (FDI) is a controlling ownership in a business enterprise in one country by an entity based in another country. Apart from being a critical driver of economic growth, foreign direct investment (FDI) is a major source of non-debt financial resource for the economic development of India. Foreign companies invest in India to take advantage of cheaper wages, special investment privileges like tax exemptions etc. For a country where foreign investment are being made, it also means achieving technical know- how and generation of employment.

Table 2: Equity capital of foreign promoter insurance sector

Top three Insurer in Inida

\begin{tabular}{|c|c|c|c|}
\hline Year & HDFC & SBI & ICICI \\
\hline $2007-2008$ & 330.46 & 260 & 363.63 \\
\hline $2008-2009$ & 466.99 & 260 & 370.73 \\
\hline $2009-2010$ & 511.68 & 260 & 370.78 \\
\hline
\end{tabular}

\begin{tabular}{|l|c|c|c|}
\hline $2010-2011$ & 518.67 & 260 & 370.78 \\
\hline $2011-2012$ & 518.67 & 260 & 370.78 \\
\hline
\end{tabular}

From 2007-2008 to 2011-2012 the foreign direct investment in insurance sector has routed to India in the form of equity capital. The top three insurers FDI position are HDFC insurance stand first place in equity capital from 2007-2008 is 330.46 is keep increasing till 2011-2012 to 518.67, SBI stand second place in equity capital is neutral from 2007-2008 to 2011-2012 is 260, ICICI stands third place for the equity capital for the 20017-2008 is 363.63 increase the equity capital to 370.78 in 2011-2012.

\subsection{Procedure for receiving Foreign Direct Investment in India Insurance companies:}

Foreign direct investment in India is routed through Automatic route and Government route: 


\section{Foreign Direct Investment in Insurance Sector: A Key for Better Insurance Penetration}

a. approval either of the government or the Reserve Bank of India in all activities/ sector as specified in the consolidated FDI policy, issued by the Government of India from time to time.

b.

Government route: FDI in activities not covered under the automatic route requires prior approval of the Government which is considered by the Foreign Investment promotion Board (FIPB) department of economic affairs, Ministry of finance.

\subsection{Benefits of foreign direct}

Government of India limits the Foreign Direct Investment in insurance sector to $49 \%$ from the existing $26 \%$. The share market has act positively in Indian market. The FDI will immensely help the insurance sector which is extremely short in investments.

There are six key benefits to increased Foreign Direct Investment in Insurance Sector:

a. Increased Insurance Penetration: population of India is more than 100 crores, the insurance penetration on the country is only around 3 percent of our gross domestic product with respect to overall premiums underwritten annually. This is far less as compared to Japan which has an insurance penetration of more than 10 percent. Increased FDI limit will strength the existing companies and will also allow the new players to come in thereby enabling more people to buy life cover.

b. Level playing Field: With the increase in foreign direct investment to 49 percent, the insurance companies will get the level playing field. So far the state owned Life Corporation of India controls around 70 percent of the life insurance market.

c. Increased Capital Inflow: Most of the private sector insurance companies have been making considerable losses. The increased FDI limit has brought some much needed relief to these firms as the inflow of more than 10,000 crore is expected in the near term. This could be go up to 40,000 crore in the medium to long term, depending on how things pan out. d. Job Creation: With more money coming in the insurance companies will be able to create more jobs to meet their targets of venturing into under insured markets through improved infrastructure, better operations and more man power.

e. Favorable to the Pension Sector: If the pension bill is passed in the parliament then the foreign direct investment in the pension funds will also be raised to 49 percent. This is because the Pension Fund regulatory Development Bill links the FDI limit in the pension sector to the insurance sector.

f. Consumer Friendly: the end beneficiary of this amendment will be common men. With more players in this sector, there is bound to be stringent competition leading to competitive quotes, improved service and better claim settlement ratio.

g. Benefit to the common man and actuaries being: More options from the foreign company are now available in the Indian market. Also now the capital increase with compare with the previous year, the insurance company can diversify their insurance sector like, Motor, Mortgage, and Health etc. Now more number of risks arises in day to day activities which increase the more investment and better benefits for customer.

h. Effect on economy: More foreign capital flows into the Indian economy. Also this more investment will lead to demand for Indian Rupee in International Money Market. There by decrease in rupee to dollar rate. As well the market speculation will also play an important role, leading to sensex and better confidence in business makers in India. More business will lead to need risk protection \& Insurance.

\section{GOVERNMENT INITIATIVE}

Government has taken enormous steps to increase the level of Insurance Penetration in India. In the recently announced union Budge 2019 the financial Ministry Nirmala Sitharaman stated that Insurance sector play a key role in the development of the country, and it is one of the sectors that need sweeping reforms, including an increase in the FDI investment ceiling to ensure higher penetration of insurance products in the country. Currently 
life insurance premiums are tax exempted up to 1.5 lacs under section $80 \mathrm{C}$ of the Income Tax Act. It comes exist when the government announces separate tax exemption limits for life insurance premium. Additional tax as an increase in the exemption limit for the life insurance premiums paid will help to enhance insurance penetration.

\subsection{Key developments}

- The Government of India has taken a number of initiatives to boost the insurance industry.

- In September 2018, National Health Protection scheme was launched under Ayushman Bharat to provide coverage of up to Rs 500,000 to more than 100 million vulnerable families. The scheme is expected to increase penetration of health insurance in India from 34 percent to 50 percent.

- Over 47.9 million famers were benefitted under Pradhan Mantri Fasal Bima Yoiana (PMFBY) in 2017-18.

- The insurance Regulatory and Development Authority of India (IRDAI) plans to issue redesigned initial public offering (IPO) guidelines for insurance companies in India, which are to looking to divest equity through the IPO route. - Bombay stock exchange along with Ebix inc to going to built insurance distribution network via distribution exchange platform.

\section{CONCLUSION}

The insurance sector is at as the crucial part in the financial improvement by giving different administrations like preparing funds, intermediating in back, advancing speculation, balancing out monetary markets and overseeing both the social and monetary hazard. Understanding the capability of protection segment in activating the investment funds for the profitable utilize for social wellbeing. Government has made different steps to enhance its equity, reach and fame. India has wonderful for absorbing greater flow of FDI in the coming years.

\section{REFERENCES}

1. Dr. Vijay Maruti Kumbhar, A study of FDI in life Insurance Sector in India.

2. Yogesh shikhare, Foreign direct investment in insurance sector in India, The business and Management Review, vol 5 (4), (2015), pg: 31-37

3. Aamir hasan, International Journal of economics and Mangement sciences, Impact Analysis of FDI on Insurance Sector in India, vol: 4(6), (2015) pp: 2-7, ISSN: 2162-6359.

4. M. Rajeev, Impact of foreign direct investment in the Indian general insurance sector, International journal of Scientific Research and modern Education (IJSRME), vol: 1(1), (2016), pp: 254-263, ISSN: 2455-5630.

5. Krunal Soni International Journal of Emerging Research in Mnagement $\&$ Technology, Impact of foreign Direct Investment in India on Insurance Industry vol: 6 (7), pp: 65-72, (2017) ISSN: 227-9359.

6. L. Terina grazy, G.paraimalarani, Shanlax Publication, Art of Social Media marketing for insurance companies, (2019), ISBN: 978-93-89146-39-4, pp: 53- 57.

7. L.Terina Grazy, G. Paraimalarani, Research Explosure, life insurance towards Corporate Social Responsibility, vol: 6, pp: 249- 253, (2018), ISSN: 2250-1940.

8. L.Terina Grazy, G. Parimalarani, International Journal of Advance and Innovative Research, Micro insurance: innovation for uplifting rural sector, vol 5, issue 4 (XVI), (2018), pp: 16- 20, ISSN: 2394-7780.
9. L.Terina Grazy , G. Parimalarani, Journal for Management studies Restaurant Business, E-Insurance: A platform for Insurance Penetration in India, vol: 118 (6), pp: 90-93, ISSN: 0097 - 8043.

10. L.Terina Grazy, G. parimalarani, Journal of emerging Technologies and Innovative Research, Bancassurance: A growing chnnel for insurance distribution, vol 5 (11), (2018), pp: 83-85, ISSN:2349- 5162

11. https://www.thehindubusinessline.com/money-and-banking/rbi-notifies49-fdi-under-automatic-route-in-insurance/article8418684.ece

12. https://www.india.com/business/6-benefits-of-increased-foreign-direct-in vestment-limit-in-insurance-sector-101998/

13. https://radingeconomics.com/india/foreign-direct-investment (30-8-2019)

14. https://www.irdai.gov.in/ADMINCMS/cms/frmGeneral_NoYearList.as px?DF=AR\&mid=11.1 (30-08-2019)

15. https://www.omicsonline.org/open-access/impact-analysis-of-fdi-on-insu rance-sector-in-india-2162-6359-1000255.php?aid=54867 (30-8-2019)

16. https://www.ibef.org/industry/insurance-sector-india.aspx (30-8 -2019)

17. https://www.statista.com/statistics/381174/insurance-penetration-in-sele cted-countries-worldwide/ (2-9-2019) 